\title{
Perbandingan Pengajaran Menggunakan Laringoskop Video dengan Laringoskop Konvensional Terhadap Keterampilan Mahasiswa Kedokteran dalam Melakukan Intubasi pada Manikin
}

Rudyanto Sedono ${ }^{1 *}$, Raden Besthadi Sukmono ${ }^{1}$, Nurul Huda El Muhammady ${ }^{1}$

1. Departemen Anestesiologi dan Terapi Intensif, Fakultas Kedokteran Universitas Indonesia, RSUPN Dr. Cipto Mangunkusumo, Jakarta, Indonesia

*penulis korespondensi

DOI: $10.55497 /$ majanestcricar.v38i3.194

\begin{abstract}
ABSTRAK
Latar Belakang: Intubasi endotrakea merupakan keterampilan penting yang perlu dikuasai oleh seorang dokter. Saat ini pengajaran intubasi pada mahasiswa kedokteran di Indonesia menggunakan laringoskop konvensional. Dalam beberapa tahun terakhir, laringoskop video mulai digunakan dalam pelayanan dan pendidikan kedokteran di dunia. Penelitian ini bertujuan untuk mengetahui sarana pengajaran yang lebih baik dalam proses pelatihan keterampilan intubasi mahasiswa kedokteran di Indonesia.

Metode: Penelitian ini bersifat eksperimental, acak, tidak tersamar, tidak berpasangan. Penelitian dimulai setelah mendapat persetujuan dari Manajer Pendidikan dan Komite Etik Penelitian Kesehatan FKUI-RSCM. Subjek pada penelitian ini melibatkan 40 mahasiswa kedokteran preklinik semester 2 yang tidak pernah mendapat kuliah atau pelatihan intubasi sebelumnya. Subjek dibagi menjadi dua kelompok pelatihan, yaitu kelompok laringoskop video dan kelompok laringoskop konvensional. Setelah dilatih selama 120 menit melakukan intubasi pada manikin, subjek diuji melakukan intubasi menggunakan laringoskop konvensional untuk mendapatkan data waktu intubasi dan jumlah upaya intubasi.

Hasil: Nilai median waktu intubasi kelompok laringoskop video 151,5 (55-383) detik dan kelompok laringoskop konvensional 56,5 (23-251) detik, dengan nilai $p<0,001$. Jumlah upaya intubasi kelompok laringoskop video 1 (1-3) kali dan kelompok laringoskop konvensional 1 (1-4) kali, dengan nilai $p=0,114$.

Kesimpulan: Pengajaran dengan laringoskop video tidak terbukti lebih baik dibandingkan dengan laringoskop konvensional terhadap keterampilan mahasiswa kedokteran FKUI dalam melakukan intubasi.
\end{abstract}

Kata kunci: laringoskop video; laringoskop konvensional; waktu intubasi; jumlah upaya intubasi 


\title{
Comparison of Teaching Using Video Laryngoscope with
Conventional Laryngoscope to FKUI Students' Skill in Intubation of
Mannequin
}

Rudyanto Sedono ${ }^{1 *}$, Raden Besthadi Sukmono ${ }^{1}$, Nurul Huda El Muhammady ${ }^{1}$

1. Departement of Anesthesiology and Intensif Care, Faculty of Medicine, Universitas Indonesia, Dr. Cipto Mangunkusumo National General Hospital, Jakarta, Indonesia

*corresponding author

\begin{abstract}
Background: Endotracheal intubation is an important skill that a physician needs to master. Currently, teaching intubation on medical students in Indonesia uses conventional laryngoscopy. In the last few years, the use of video laryngoscopy has been introduced for medical and educational purposes globally. This study was aimed to investigate a better tool in teaching intubation skills for medical students in Indonesia.

Methods: It was a randomized experimental study. It began after obtaining approval from Education Manager and Ethics Committee of Health Research FKUI-RSCM Forty pre-clinical medical students in $2^{\text {nd }}$ term who had never received a lecture or intubation training before were involved in this study. Subjecrs were divided into two training groups, namely video laryngoscope groups and conventional laryngoscope groups. After being trained for 120 minutes of intubation on the mannequin, they were tested for intubation using a conventional laryngoscope to obtain data on intubation time and the number of intubation attempts.

Results: Median duration of intubation in video laryngoscope group was 151.5 (55-383) seconds while in conventional laryngoscope group was 56.5 (23-251), p-value $<0.001$. Number of attempts at intubation in laryngoscope video group was 1 (1-3) times whereas in conventional laryngoscope group was 1 (1-4) times, $p$-value $=0.114$.

Conclusion: The use of video laryngoscope is not better than conventional laryngoscope in teaching intubation for FMUI students.
\end{abstract}

Keyword: video laryngoscope; conventional laryngoscope; intubation time; number of intubation attempts. 


\section{PENDAHULUAN}

Kegawatdaruratan medis adalah cabang ilmu kedokteran yang berkaitan dengan pengelolaan penyakit akut dan cedera pada seluruh kelompok usia. ${ }^{1}$ Salah satu keterampilan yang harus dikuasai pada kegawatdaruratan medis adalah pengelolaan jalan napas. ${ }^{2}$ Baku emas pengelolaan jalan napas yang utama adalah intubasi endotrakea, yaitu tindakan pemasangan pipa endotrakea untuk menguasai dan mempertahankan patensi jalan napas..$^{3-5}$

Beberapa studi telah dilakukan di sejumlah negara terkait tingginya angka kegagalan intubasi. Penelitian di Amerika Serikat melaporkan tingkat kegagalan intubasi terjadi pada $50 \%$ kasus yang dilakukan oleh tenaga medis terlatih. Di Inggris, terdapat $65 \%$ kasus gagal intubasi oleh paramedis terlatih. ${ }^{6}$ Penelitian lain mendapatkan $6-14 \%$ insiden gagal intubasi yang tidak terdeteksi oleh tenaga kesehatan terlatih pada kasus gawat darurat. ${ }^{7}$ Pada tahun 2006, Henry dkk. melakukan penelitian tentang jumlah upaya yang dibutuhkan untuk keberhasilan intubasi dalam 1941 kasus di luar rumah sakit, penelitian tersebut menyatakan bahwa $68,5 \%$ intubasi berhasil pada upaya pertama, $21,1 \%$ pada upaya kedua, 7,1\% pada upaya ketiga, dan 3,2\% pada upaya lebih dari tiga kali. ${ }^{8}$

Pengajaran keterampilan intubasi pada mahasiswa Fakultas Kedokteran Universitas Indonesia (FKUI) saat ini menggunakan metode pengajaran empat langkah dengan laringoskop konvensional. Kekurangan dari pengajaran intubasi dengan laringoskop konvensional adalah peserta didik tidak dapat melihat apa yang dilihat oleh instruktur, begitu juga sebaliknya.

Dalam satu dekade terakhir, beberapa laringoskop video telah digunakan dalam praktik klinis. Laringoskop video menggabungkan kamera video mikro dengan permukaan bawah bilah laringoskop sehingga kamera tersebut dapat menampilkan gambaran jalan napas pasien pada monitor. Laringoskop video juga memungkinkan proses supervisi saat intubasi seperti laringoskop konvensional karena instruktur dapat melihat hal yang dilihat oleh peserta didik dalam waktu bersamaan. ${ }^{9}$

Herbstreit dkk.7 melakukan penelitian yang membandingkan metode pengajaran intubasi pada mahasiswa klinik yang dilatih selama 2 minggu pada pasien kemudian diuji dengan manikin. Studi tersebut mendapatkan bahwa angka keberhasilanintubasipada mahasiswayang dilatih menggunakan laringoskop video C-MAC ${ }^{\circledR}$ rata-rata 11 detik lebih cepat dibandingkan yang dilatih menggunakan laringoskop konvensional. Saat ini, laringoskop video mulai digunakan dalam pelayanan dan pendidikan kedokteran. C-MAC ${ }^{\circledR}$ menggabungkan bentuk bilah yang mirip dengan laringoskop konvensional dengan kamera mikro. Pengajaran intubasi dengan laringoskop video tidak pernah dilakukan di FKUI. Tujuan penelitian ini adalah untuk mengetahui perbandingan pengajaran menggunakan laringoskop video dengan laringoskop konvensional terhadap keterampilan mahasiswa kedokteran FKUI dalam melakukan intubasi pada manikin, dengan menilai waktu intubasi dan jumlah upaya intubasi.

\section{METODE PENELITIAN}

\section{Desain Penelitian}

Penelitian ini bersifat eksperimental, acak, tidak tersamar, tidak berpasangan. Penelitian ini dilaksanakan di ruang Skill Lab, Gedung Rumpun Ilmu Kesehatan Universitas Indonesia, Depok pada bulan Februari 2018. Penelitian dimulai setelah mendapat persetujuan dari Manajer Pendidikan FKUI (2111/UN2.F1.D1.2/ PDP.02.01.02/2018) dan Komite Etik Penelitian FKUI-RSCM (RSUPN Dr. Cipto Mangunkusumo) terkait etika dalam penelitian (1139/UN2.F1/ ETIK/2017).

\section{Jumlah Sampel dan Kriteria Subjek}

Berdasarkan perhitungan besar sampel yang dilakukan, dibutuhkan jumlah sampel untuk masing-masing-masing kelompok pelatihan adalah 20 orang, dengan total sampel seluruhnya adalah 40 orang. Pengambilan sampel dilakukan dengan metode voluntary sampling. Peneliti melakukan presentasi pengenalan tentang intubasi dan penelitian sekaligus menyebarkan undangan pada mahasiswa mahasiswa kedokteran preklinik di Fakultas Kedokteran Universitas Indonesia (FKUI) semester 2 pada tahun 2019 untuk mengikuti penelitian. Mahasiswa yang berminat kemudian dicatat. Pendaftaran ditutup ketika jumlah sampel yang dibutuhkan sudah terpenuhi. Peserta yang 
bersedia akan menandatangani lembar informed consent. Peserta yang telah mengikuti pelatihan intubasi sebelumnya tidak diikutsertakan dalam penelitian. Peserta yang berhenti mengikuti pelatihan dan pengambilan data selama penelitian berlangsung akan dikeluarkan.

\section{Protokol Penelitian}

Daftar tilik pengajaran yang digunakan telah divalidasi oleh tiga orang staf pengajar Departemen Anestesiologi dan Terapi Intensif FKUI-RSCM. Seluruh instruktur dan penguji pelatihan menerima pengarahan tentang metode pengajaran dan kriteria penilaian dalam pelatihan dari staf pengajar Departemen Anestesiologi dan Terapi Intensif FKUI-RSCM untuk menyamakan persepsi tentang penelitian. Kesepahaman antar penguji dinilai dengan uji Inter-Rater Reliability degan menggunakan uji statistik Interclass Correlation.

Peserta dibagi menjadi dua kelompok perlakuan, yaitu kelompok laringoskop video dan kelompok laringoskop konvensional. Setiap kelompok perlakuan dibagi menjadi 2 kelompok kecil yang masing-masing terdiri dari 10 orang. Pembagian menjadi empat kelompok dilakukan secara acak berdasarkan nomor daftar hadir. Proses pengacakan dilakukan dengan menggunakan nomor urut daftar hadir oleh salah satu penguji menggunakan halaman situs www.randomizer. org, dengan metode simple random allocation. Laringoskop video yang digunakan pada penelitian ini adalah $\mathrm{C}-\mathrm{MAC}^{\circledR}$.

Instruktur dan penguji pada pelatihan adalah peserta Program Pendidikan Dokter Spesialis AnestesiologidanTerapilntensifFKUI-RSCMtahap paripurna dengan supervisi dari staf pengajar Departemen Anestesiologi dan Terapi Intensif FKUI-RSCM. Pelatihan berlangsung selama 120 menit dengan metode pengajaran empat langkah. Setiap peserta diberi kesempatan untuk melakukan intubasi hingga berhasil sebanyak 2 kali. Setelah pelatihan selesai, seluruh peserta kembali diacak dan dibagi menjadi 4 kelompok baru untuk ujian akhir. Pada ujian akhir, penguji tidak akan menguji peserta yang telah mereka latih pada sesi pelatihan. Selanjutnya, seluruh peserta menjalani ujian praktik mandiri dengan menggunakan laringoskop konvensional secara bergantian.

Pada saat ujian praktik, dilakukan penilaian terhadapt waktu intubasi dan jumlah upaya intubasi. Waktu intubasi adalah waktu yang dihitung mulai saat peserta memegang laringoskop hingga paru manikin mengembang saat dipompa dengan Bag Valve Mask. Jumlah Upaya intubasi adalah total upaya memasukkan pipa endotrakea hingga tepat dapat melewati pita suara manikin. Satu kali upaya didefinisikan sebagai usaha melakukan intubasi yang ditandai dengan pipa endotrakea melewati gigi incisivus anterior.

\section{Analisa Statisik}

Pengolahan data dilakukan dengan menggunakan program Statistical Package for Social Sciences (SPSS) versi 20.0. Uji normalitas data dilakukan dengan uji Shapiro-Wilk. Bila sebaran data normal, uji T tidak berpasangan akan digunakan untuk menentukan apakah terdapat perbedaan antar variabel. Bila sebaran data tidak normal, akan digunakan uji Mann Whitney.

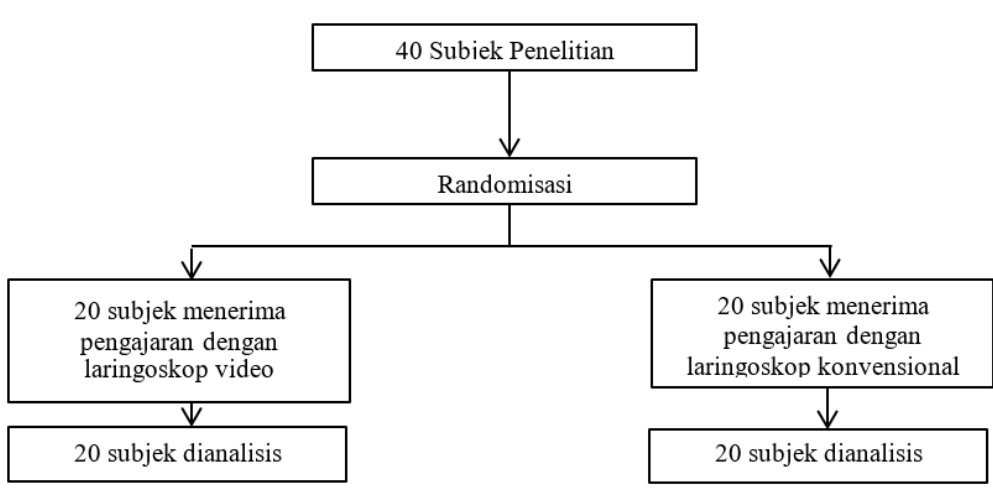

Gambar 1. Skema Penelitian 


\section{HASIL PENELITIAN}

Pada proses perekrutan sampel, didapatkan 40 subjek penelitian yang memenuhi kriteria inklusi serta bersedia menandatangani formulir persetujuan. Seluruh subjek penelitian dapat hadir pada hari pengambilan data. Semua subjek penelitian mengikuti proses penelitian hingga selesai, tidak ada subjek yang dikeluarkan dari penelitian.

Tabel 1 menunjukkan karakteristik subjek penelitian berupa usia, jenis kelamin, IPK (Indeks Prestasi Kumulatif) dan pengalaman dalam mengikuti pelatihan intubasi sebelumnya. Karakteristik subjek berupa jenis kelamin menunjukkan perempuan berjumlah lebih banyak pada kedua kelompok pelatihan. Seluruh subjek penelitian tidak pernah mengikuti pelatihan intubasi sebelumnya.

Data perbandingan waktu intubasi pada kedua kelompok dapat dilihat pada Tabel 2 . Kelompok yang mendapat pengajaran intubasi menggunakan laringoskop video membutuhkan waktu intubasi yang signifikan lebih lama dibandingkan dengan kelompok yang mendapat pengajaran intubasi dengan laringoskop konvensional $(p<0,001)$.

Tabel 3 menunjukkan jumlah upaya intubasi hingga subjek dapat memasukkan pipa endotrakeal melewati pita suara pada manikin tidak berbeda bermakna, baik pada kelompok laringoskop video ataupun kelompok laringoskop konvensional $(p=0,114)$.

Tabel 1. Karakteristik subjek penelitian

\begin{tabular}{lll}
\hline Karakteristik & $\begin{array}{l}\text { Laringoskop } \\
\text { Video }(\mathbf{n = 2 0})\end{array}$ & $\begin{array}{l}\text { Laringoskop } \\
\text { Konvensional }(\mathbf{n = 2 0})\end{array}$ \\
\hline $\begin{array}{l}\text { Usia (tahun), median (minimum-maksimum) } \\
\text { Jenis kelamin, } \mathrm{n}(\%)\end{array}$ & $18(17-20)$ & $18(16-19)$ \\
Laki-laki & $9(56,3)$ & $7(43,8)$ \\
Perempuan & $11(45,8)$ & $13(54,2)$ \\
IPK, median (minimum-maksimum) & $3,78(3,32-3,97)$ & $3,81(3,43-4,00)$ \\
Pernah mengikuti pelatihan Intubasi & $0(0,0)$ & $0(0,0)$ \\
\hline
\end{tabular}

Tabel 2. Perbandingan waktu intubasi yang dibutuhkan oleh kelompok pelatihan laringoskop video dan laringoskop konvensional

\begin{tabular}{lll}
\hline Kelompok & Waktu Intubasi (detik) & Nilai P \\
\hline Laringoskop Video & $151,5(55-383)$ & $<0,001^{*}$ \\
Laringoskop Konvensional & $56,5(23-251)$ & \\
\hline ujI IVann-Whitney & &
\end{tabular}

Tabel 3. Perbandingan jumlah upaya intubasi pada kelompok laringoskop video dan laringokop konvensional

\begin{tabular}{lll}
\hline Kelompok & Jumlah Upaya (kali) & Nilai P \\
\hline Laringoskop Video & $1(1-3)$ & $<0,114^{*}$ \\
Laringoskop Konvensional & $1(1-4)$ & \\
\hline ujI Vann-Whitney & &
\end{tabular}




\section{PEMBAHASAN}

Intubasi endotrakea merupakan keterampilan penting yang perlu dikuasai oleh seorang dokter. Saat ini, pengajaran intubasi pada mahasiswa kedokteran di Indonesia masih rutin menggunakan laringoskop konvensional. Dalam beberapa tahun terakhir, laringoskop video mulai digunakan dalam pelayanan dan pendidikan kedokteran. Tujuan penelitian ini adalah untuk mengetahui perbandingan pengajaran menggunakan laringoskop video dengan laringoskop konvensional terhadap keterampilan mahasiswa kedokteran dalam melakukan intubasi pada manikin, dengan menilai waktu intubasi dan jumlah upaya intubasi.

Waktu intubasi pada kelompok dengan laringoskop video lebih lama dibandingkan kelompok dengan laringoskop konvensional $(p<$ $0,001)$. Hal ini dapat terjadi karena kelompok pelatihan laringoskop video mengalami kesulitan saat ujian dengan menggunakan laringoskop konvensional, disebabkan mereka harus beradaptasi kembali dengan alat yang baru mereka kenal, yaitu laringoskop konvensional.

Laringoskop video memiliki kelebihan tersendiri dibandingkan laringoskop konvensional. Dengan tekanan yang lebih sedikit, visualisasi laring dapat lebih mudah tercapai menggunakan laringoskop video. Namun, tampilan dua dimensi pada monitor membuat operator kehilangan persepsi kedalaman (perception of depth). ${ }^{10} \mathrm{Hal}$ serupa terjadi pada operator yang melakukan tindakan pembedahan secara laparoskopi dengan mikroskop. Kondisi tersebut membuat operator kehilangan persepsi tiga dimensi sehingga dibutuhkan latihan yang cukup untuk beradaptasi dari tampilan dua dimensi ke tiga dimensi dan sebaliknya terkait koordinasi tangan dan mata (hand-eye coordination), persepsi jarak, dan tekanan yang dibutuhkan. ${ }^{10-13}$ Perlu dilakukan penelitian lebih lanjut dengan kondisi kedua kelompok terlebih dahulu dilatih dan diuji dengan laringoskop konvensional, kemudian kelompok intervensi dilatih dengan laringoskop video dan kelompok kontrol tetap dilatih dengan laringoskop konvensional. Selanjutnya, kedua kelompok kembali diuji dengan laringoskop konvensional.

Pada penelitian yang dilakukan oleh Herbstreit dkk., didapatkan waktu intubasi pada kelompok yang dilatih dengan laringoskop video lebih cepat rata-rata 11 detik dibandingkan dengan kelompok yang dilatih dengan laringoskop konvensional.7 Penelitian tersebut memiliki beberapa perbedaan mendasar, yaitu subjek adalah mahasiswa yang sudah memasuki rotasi klinik, lama pelatihan dua minggu, dan objek pelatihan adalah pasien. Subjek yang memasuki rotasi klinik sudah pernah mendapatkan pelatihan intubasi sebelumnya sehingga mereka sudah berpengalaman dalam melakukan intubasi dengan laringoskop konvensional. Masa pelatihan dua minggu memberikan kesempatan kepada subjek untuk dapat berlatih melakukan intubasi berulang kali sehingga kompetensi yang dicapai akan lebih baik. Objek pelatihan pada pasien berbeda dengan manikin karena manikin memiliki karakteristik yang lebih lebih kaku.

Salah satu faktor yang dapat memengaruhi lamanya waktu intubasi adalah penentuan saat dimulainya penghitungan waktu intubasi. Pada penelitian ini, waktu intubasi mulai dihitung pada saat subjek memegang laringoskop. Subjek membutuhkan waktu yang cukup lama mulai dari memegang laringoskop hingga bilah laringoskop masuk ke dalam mulut manikin. Hal ini mungkin menyebabkan kelompok yang dilatih dengan laringoskop video memiliki waktu intubasi lebih lama karena belum terbiasa dengan laringoskop konvensional. Sebaiknya penghitungan waktu intubasi dimulai saat bilah laringoskop melewati gigi incicivus untuk mengurangi bias akibat lamanya mempersiapkan laringoskop.

Metode pengajaran empat langkah digunakan pada penelitian ini. Metode ini telah digunakan di berbagai institusi pendidikan kedokteran di dunia, termasuk Universitas Indonesia. Walaupun metode empat langkah ini memiliki keunggulan, namun metode ini tetap memiliki keterbatasan. Metode pengajaran empat langkah yang diperkenalkan oleh Peyton ini sebenarnya dirancang untuk metode pengajaran satu banding satu antara pengajar dan siswa, terutama pada langkah ketiga dari metode ini, sehingga metode ini masih membutuhkan penyempurnaan lebih lanjut. ${ }^{14,15}$ Pada penelitian ini, metode pengajaran dilakukan secara berkelompok sehingga kondisi tersebut dapat mempengaruhi capaian tujuan pembelajaran 
meskipun perlakuan pada kedua kelompok sama. Penelitian lebih lanjut dengan metode pengajaran satu banding satu antara pengajar dan subjek penelitian perlu dilakukan.

Hasil penilaian intubasi pada manikin mungkin menunjukkan hasil yang berbeda bila dilakukan pada manusia. Terdapat beberapa perbedaan karakteristik antara manikin dengan manusia, antara lain wajah dan lidah maneken lebih kaku, mulut maneken sudah terbuka sejak awal, berat kepala maneken lebih ringan dari kepala manusia, dan warna mukosa jalan napas manikin lebih terang dibandingkan mukosa manusia. ${ }^{16}$ Berdasarkan alasan tersebut, tindakan intubasi pada pasien akan lebih sulit dibandingkan dengan pada manikin. Bila memungkinkan, penelitian selanjutnya dapat dilakukan langsung pada pasien untuk mendapatkan gambaran sebenarnya mengenai keterampilan subjek dalam melakukan intubasi setelah subjek penelitian dilatih dan dianggap telah menguasai teknik intubasi dengan benar.

Penilaian kinerja subjek dalam menguasai keterampilan intubasi tidak hanya dapat dilihat dari hasil akhir, tetapi proses yang dilalui hingga mendapatkan hasil tersebut pun perlu dinilai. Pada penelitian ini, salah satu poin penilaian adalah waktu intubasi. Waktu intubasi yang dihasilkan oleh subjek tidak dapat secara langsung menjelaskan permasalahan yang dialami oleh subjek dalam melakukan intubasi. Penilaian secara spesifik dan umpan balik dari tiap subjek perlu dikaji. Hal ini sesuai dengan teori yang dicetuskan oleh Duvivier dkk. dan Ericsson dkk. tentang deliberate practice, yaitu upaya peningkatan kinerja suatu keterampilan melalui pelatihan yang terfokus, merujuk pada penilaian spesifik, dan umpan balik dari subjek pelatihan. ${ }^{17,18}$

Jumlah upaya intubasi antara kedua kelompok menunjukkan hasil yang tidak berbeda bermakna $(p=0,114)$. Meskipun perbandingan waktu intubasi secara statistik terdapat perbedaan bermakna, namun perbandingan jumlah upaya intubasi pada kedua kelompok tidak terdapat perbedaan bermakna. Hal ini dapat terjadi karena semua subjek penelitian pada kedua kelompok sama-sama memiliki pengalaman melakukan intubasi hingga berhasil dengan jumlah yang sama. Saat pelatihan, semua subjek diberi kesempatan melakukan intubasi hingga berhasil sebanyak dua kali. Kondisi ini mengakibatkan subjek penelitian telah mengetahui target penempatan pipa endotrakea secara tepat dan tidak melakukan upaya intubasi sebelum mereka berhasil mendapatkan visualisasi target tersebut. Hasil penelitian ini selaras dengan penelitian yang dilakukan oleh Zhao dkk. yang menyebutkan bahwa tindakan intubasi terbagi menjadi dua, visualisasi pita suara dan penempatan pipa endotrakea. Visualisasi pita suara merupakan bagian tersulit pada tindakan ini. $^{5}$

Penelitian ini memiliki beberapa keterbatasan. Pertama, tidak adanya pengenalan teknik dasar intubasi dengan menggunakan laringoskop konvensional sebelum subjek dibagi menjadi dua kelompok pelatihan. Walaupun laringoskop konvensional dan laringoskop video $\mathrm{CMAC}^{\circledR}$ memiliki karakteristik yang hampir sama, subjek penelitian tetap memerlukan waktu untuk berdaptasi dengan alat yang baru mereka gunakan. Hal ini terlihat dari data yang diambil pada ujian yang menggunakan laringoskop konvensional, dimana subjek yang dilatih dengan laringoskop video memiliki waktu intubasi yang lebih lama dibandingkan dengan yang dilatih dengan laringoskop konvensional. Keterbatasan kedua, proses pelatihan dan pengambilan data yang dilakukan berlangsung sangat singkat, yaitu hanya satu hari. Hal ini mengakibatkan subjek penelitian hanya memiliki waktu yang sangat terbatas untuk melakukan latihan dengan alat yang digunakan. Singkatnya waktu pelatihan mempengaruhi tingkat retensi keterampilan subjek penelitian terhadap keterampilan yang didapat.

\section{SIMPULAN}

Pengajaran menggunakan laringoskop video tidak terbukti lebih baik dibandingkan dengan laringoskop konvensional terhadap keterampilan mahasiswa kedokteran dalam melakukan intubasi pada manikin.

\section{KONFLIK KEPENTINGAN}

Penulis menyatakantidak ada konflikkepentingan dalam penulisan artikel ini. 


\section{DAFTAR PUSTAKA}

1. Royal College of Physicians and Surgeons of Canada. Objective of training in emergency medicine. 2011.

2. Gismalla MD, Alawad AA. Undergraduate emergency medicine education: problems and challenges. Austin Emerg Med. 2017;3(1):1049.

3. Hagberg CA, Artime CA. Airway management in the adult. In Miller RD, editor. Miller's anesthesia 8th Ed. Philadelphia: Elsevier/ Saunders; 2015. p. 1647.

4. Nouruzi-Sedeh P, Schumann M, Groeben H. Laryngoscopy via Macintosh blade versus GlideScope success rate and time for endotracheal intubation in untrained medical personnel. J Am Soc Anesthesiol. 2009;110(1):32-7.

5. Zhao $H$, Feng $Y$, Zhou $Y$. Teaching tracheal intubation: Airtraq is superior to Macintosh laryngoscope. BMC Med Educ. 2014;14(1):144.

6. Cook TM, Hommers C. New airways for resuscitation? Resuscitation. 2006;69(3):371-87.

7. Herbstreit F, Fassbender $P$, Haberl $H$, Kehren $C$, Peters J. Learning endotracheal intubation using a novel videolaryngoscope improves intubation skills of medical students: Anesth Analg. 2011 Jun;1:586-90.

8. Wang HE, Yealy DM. How many attempts are required to accomplish out-of-hospital endotracheal intubation?. Acad Emerg Med. 2006 Apr;13(4):372-7.

9. Sakles JC, Mosier J, Chiu S, Cosentino $\mathrm{M}$, Kalin L. A comparison of the C-MAC video laryngoscope to the Macintosh direct laryngoscope for intubation in the emergency department. Ann Emerg Med. 2012 Dec;60(6):739-48.

10. Channa AB. Video laryngoscopes. Saudi J Anaesth. 2011;5(4):357-9.

11. Hu JSL, Lu J, Tan WB, Lomanto D. Training improves laparoscopic tasks performance and decreases operator workload. Surg Endosc. 2016 May;30(5):1742-6.

12. Lee JK, Lee S-H, Kim JG, Lee YS, Lee KY, Park SJ, et al. Three dimensional laparoscopy improves surgical performance: comparative study in a cadaver. J Minim Invasive Surg.
2016 Jun 15;19(2):75-8.

13. Yadav $\mathrm{Y}$, Parihar $\mathrm{V}$, Ratre $\mathrm{S}$, Kher $\mathrm{Y}$, Iqbal $\mathrm{M}$. Microneurosurgical skills training. J Neurol Surg Part Cent Eur Neurosurg. 2015 Apr 27;77(02):146-54.

14. Krautter M, Dittrich R, Safi A, Krautter J, Maatouk I, Möltner A, et al. Peyton's fourstep approach: differential effects of single instructional steps on procedural and memory performance; a clarification study. Adv Med Educ Pract. 2015 May;399.

15. Nikendei C, Huber J, Stiepak J, Huhn D, Lauter J, Herzog W, et al. Modification of Peyton's four-step approach for small group teaching - a descriptive study. BMC Med Educ. 2014 Dec;14(1).

16. Whitten, C. Tips to teaching intubation. [disitasi pada 20/5/2018]. Tersedia dari: https://airwayjedi.com/

17. Duvivier RJ, van Dalen J, Muijtjens AM, Moulaert VR, van der Vleuten CP, Scherpbier AJ. The role of deliberate practice in the acquisition of clinical skills. BMC Med Educ. 2011 Dec;11(1).

18. Ericsson KA, Krampe RT, Tesch-Romer C. The role of deliberate practice in the acquisition of expert performance. Psychological Review. 1993;100(3):363-406. 